\title{
HOMINE CATHÓLICO': fragmentos do livro didático "Elementos de História Natural: segundo Os Programas Officiais. Admissão a várias Escolas Superiores \\ (Curso Médio). 3 ed. São Paulo: Collecção FTD, 1923”.
}

Ana Elizabeth Santos Alves

Universidade Estadual do Sudoeste da Bahia - UESB ana_alves183@hotmail.com

Ivana Teixeira Silveira Universidade Estadual do Sudoeste da Bahia - UESB ivanateixeiras@gmail.com

O livro Elementos de História Natural: segundo Os Programas Officiais. Admissão a várias Escolas Superiores (Curso Médio). 3 ed. São Paulo: Collecção FTD, 1923.(328 p.), encontrado em uma biblioteca particular, destinado às escolas da ordem Marista, instituições públicas e privadas do início do século XX, nos ajuda a recuperar algumas concepções ideológicas da Igreja Católica, responsável na época pela formação de um determinado tipo de homem. O período de circulação deste livro no Brasil foi palco de movimentos políticos e sociais, como as lutas reivindicatórias dos trabalhadores por melhores condições de vida e de trabalho, pressões da burguesia industrial e dos setores dominantes pela formação do "cidadão" republicano, descaracterização dos trabalhadores enquanto classe e controle dos movimentos sociais pela classe dominante, novas diretrizes econômicas e ideológicas sustentadas pelo nacionalismo, tenentismo e o catolicismo.

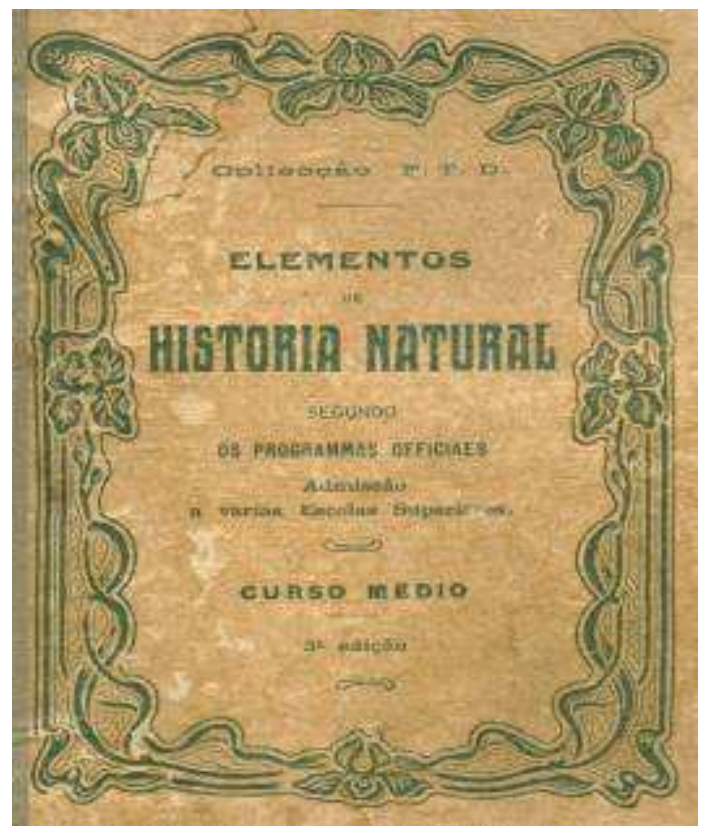

Figura 1: Capa do livro

Ao manusearmos o documento encontramos no centro da folha de rosto o símbolo da ordem Marista. No verso, um texto explicando que o livro antes de ser publicado foi examinado por um membro de uma ordem religiosa, a fim de receber a aprovação oficial do ponto de vista moral e doutrinário de um censor da Igreja Católica - NIHIL OBSTAT 
(significa "nada impede". NIHIL OBSTAT, Sti. Pauli, 26 Martti 1922, Can. Dor. Martins Ladeira), antes de ser impresso.

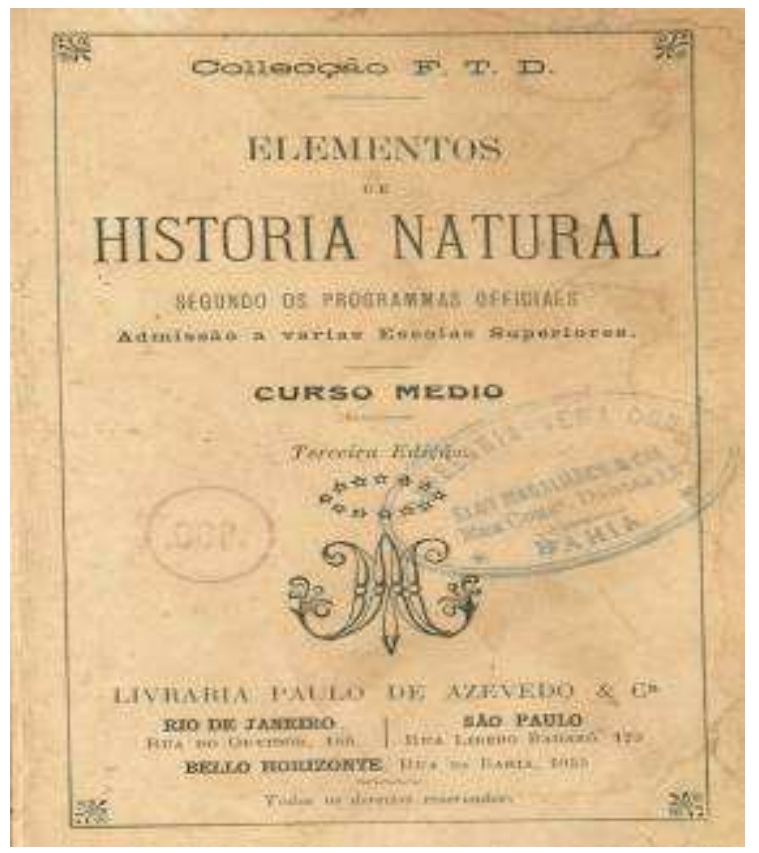

Figura 2: Folha de rosto

O livro foi publicado pela FTD (Frère Théophane Durant) e distribuído pela Livraria Paulo de Azevedo \& Cia, em São Paulo. A coleção de livros didáticos publicados pela editora na época contém também livros de "Physica" e "Chimica". A Editora FTD nasceu no Brasil, em 1902, para atender as necessidades educativas dos Irmãos Maristas. A sigla da editora é uma homenagem à Frère Théophane Durand, que em 1883 assumiu a diretoria da Congregação Marista. Naquela época a produção gráfica nacional era ainda muito precária, os originais dos livros eram enviados pelo porto de Santos para Lyon, na França, para que fossem impressos, quando voltavam eram revistos até que se chegasse à publicação definitiva, de capa dura, em quantidade suficiente para atender ao mercado escolar brasileiro do início do século XX. Os livros eram escritos pelos Irmãos Maristas, entretanto, só aparecia o logotipo da Congregação com a sigla FTD. (www.ftd.com.br).

A ordem Marista é originária da França. A sua história se confunde com a história e a filosofia do fundador, o Pe Marcelino Champagnat. Nascido em 1789, em um aldeia pobre onde a maioria dos jovens e adultos era anlafabeta, numa época em que iniciava a Revolução Francesa. Filho de família cristã muito religiosa e de grande devoção a Maria. Aos 14 anos por influência de um padre que visitava a região, sentiu-se chamado por Deus e parte para a vida sacerdotal. No Seminário Maior de Lion conheceu os colegas João Maria Vianney e João Cláudio Colin, junto com eles imaginavam fundar uma nova congregação que abrigasse padres, religiosas e uma Ordem Terceira, levando o nome de Maria - a sociedade de Maria, cuja missão seria "cristianizar a sociedade". Em 1817, o Pe Marcelino e os seus primeiros discípulos (João Maria Vianney e João Cláudio Colin) fundam a "Congregação dos Irmãozinhos de Maria" em La Valla, cidade em que atuava como vigário, berço dos Irmãos Maristas. Outros irmãos foram se aproximando do grupo, 
dando origem a criação de várias escolas. (MISSÃO EDUCATIVA MARISTA, 2000; www.maristas.org.br).

O livro Elementos de História Natural traz noções preliminares a respeito de várias questões relacionadas à ciência. O seu objetivo central é descrever e classificar os diferentes corpos encontrados no globo terrestre, com o propósito de identificar a sua origem, seu modo de formação, a estrutura externa e interna de corpos inertes e seres vivos; reinos da natureza (mineral, vegetal, animal e hominal); origens dos seres; raça, variedade, espécie; orgãos: funções e aparelhos.

As noções descritas no texto nos chamam atenção para o uso ideológico das explicações religiosas a respeito do conceito de homem e da sua criação, pedagogia responsável pela formação do "homem católico". O conteúdo didático do livro contém mensagens defendendo uma determinada concepção de homem, expondo-as como "verdades" definitivas, tendo como pano de fundo reproduzir a hierarquização da socieddade oligárquica da época e preservar uma educação conservadora. A título de exemplo selecionamos algumas partes do livro a fim de ilustrar os nossos argumentos e servir de ponto de partida para algumas análises.

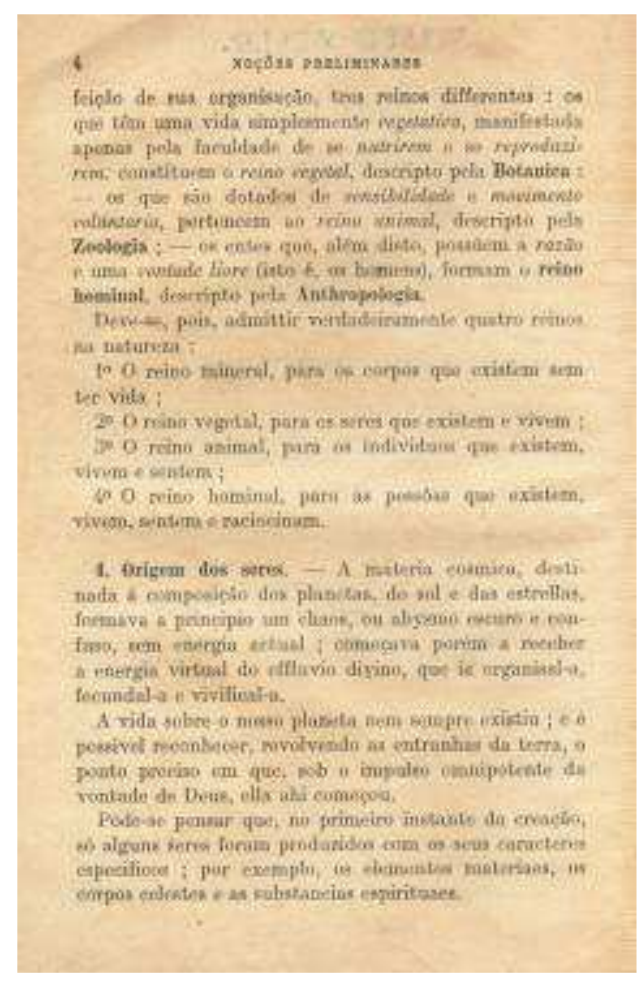

Figura 3: A origem dos seres humanos 


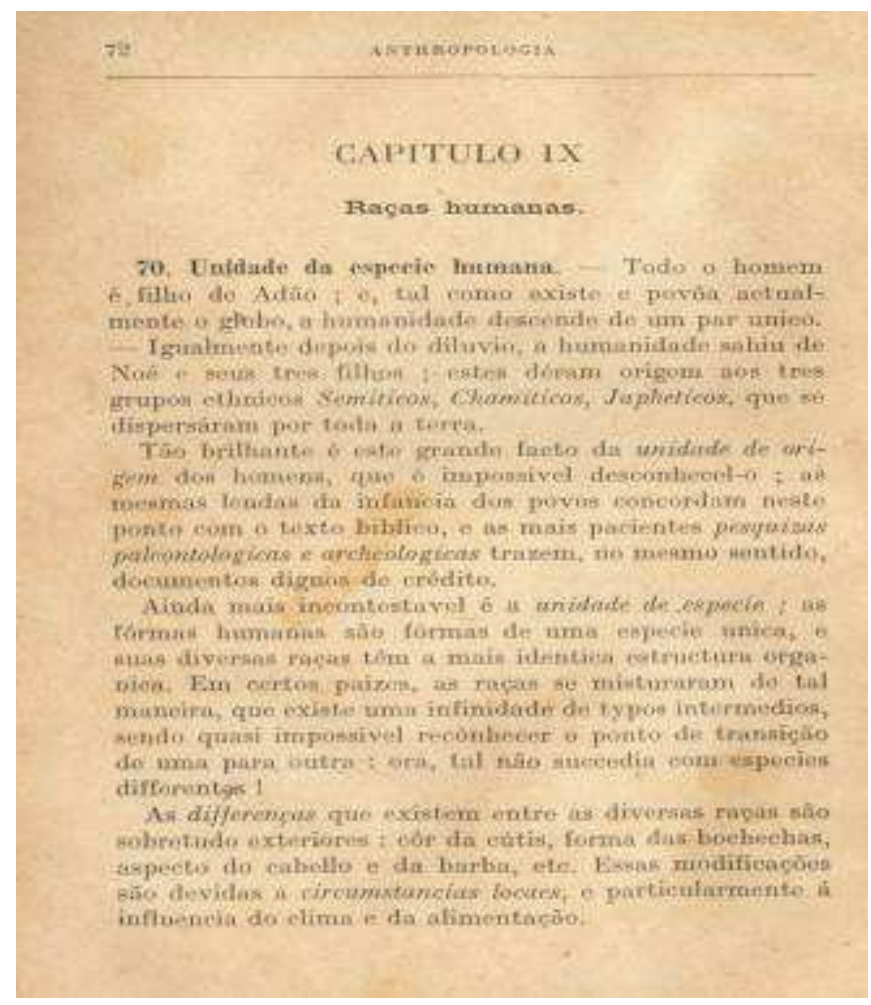

Figura 4: A raça humana

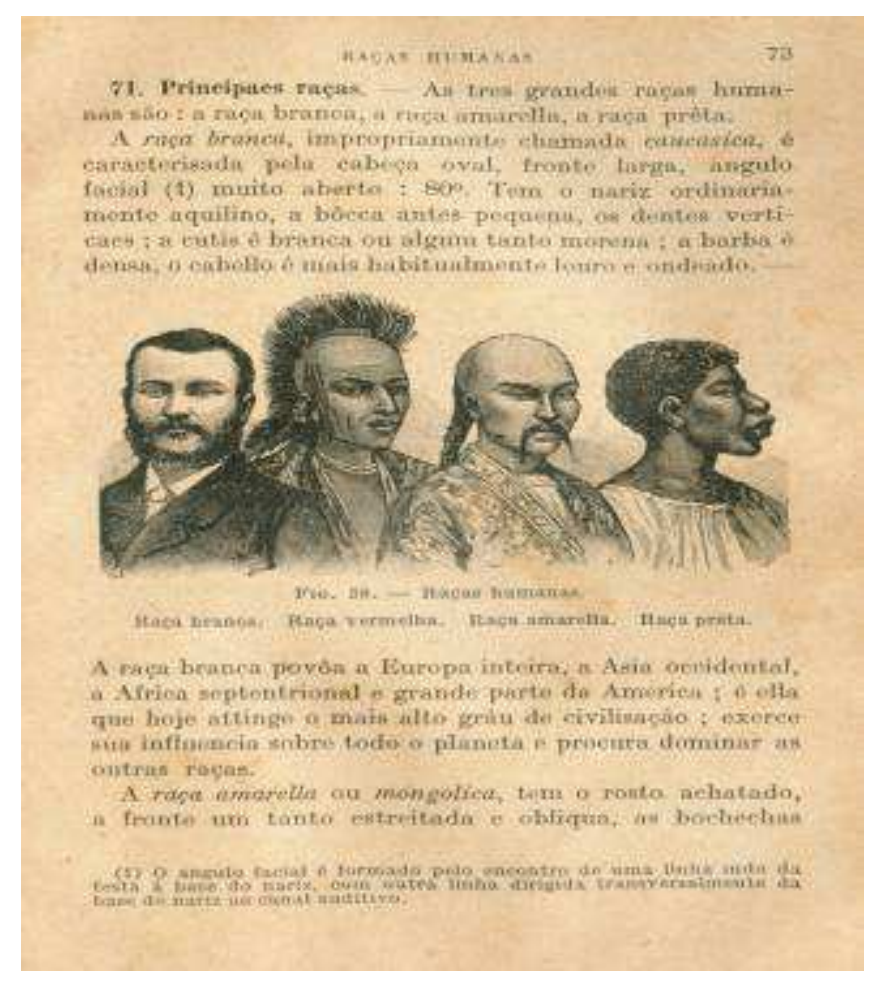

Figura 5: Principais Raças 


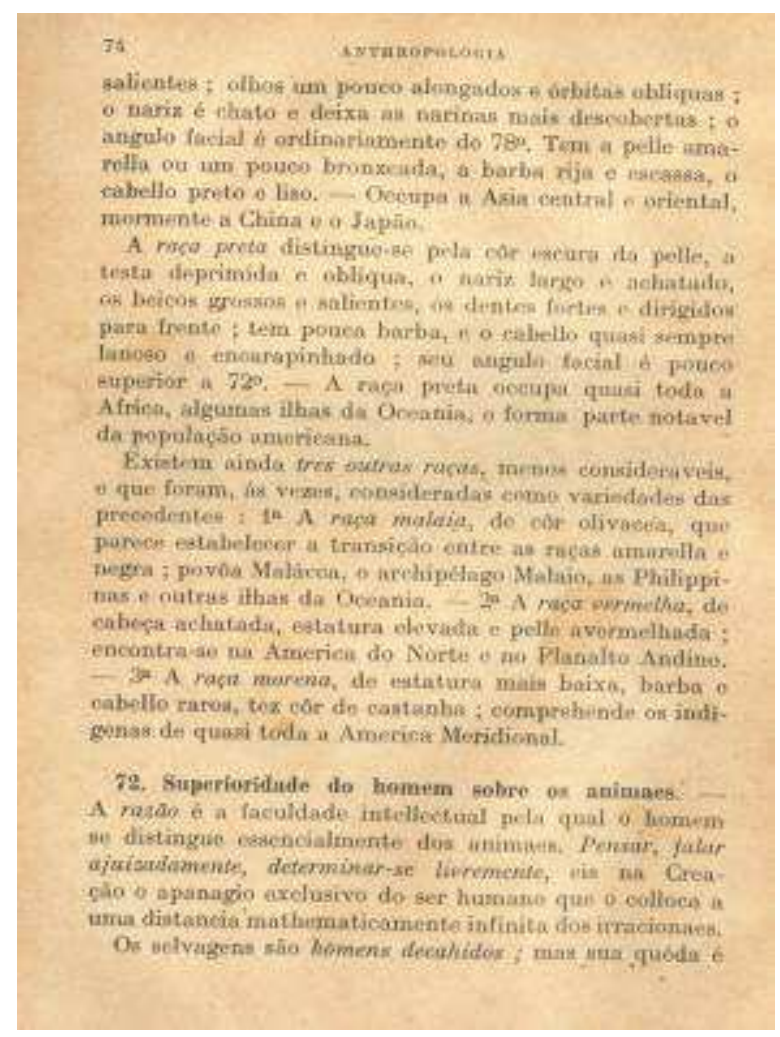

Figura 6: A raça humana

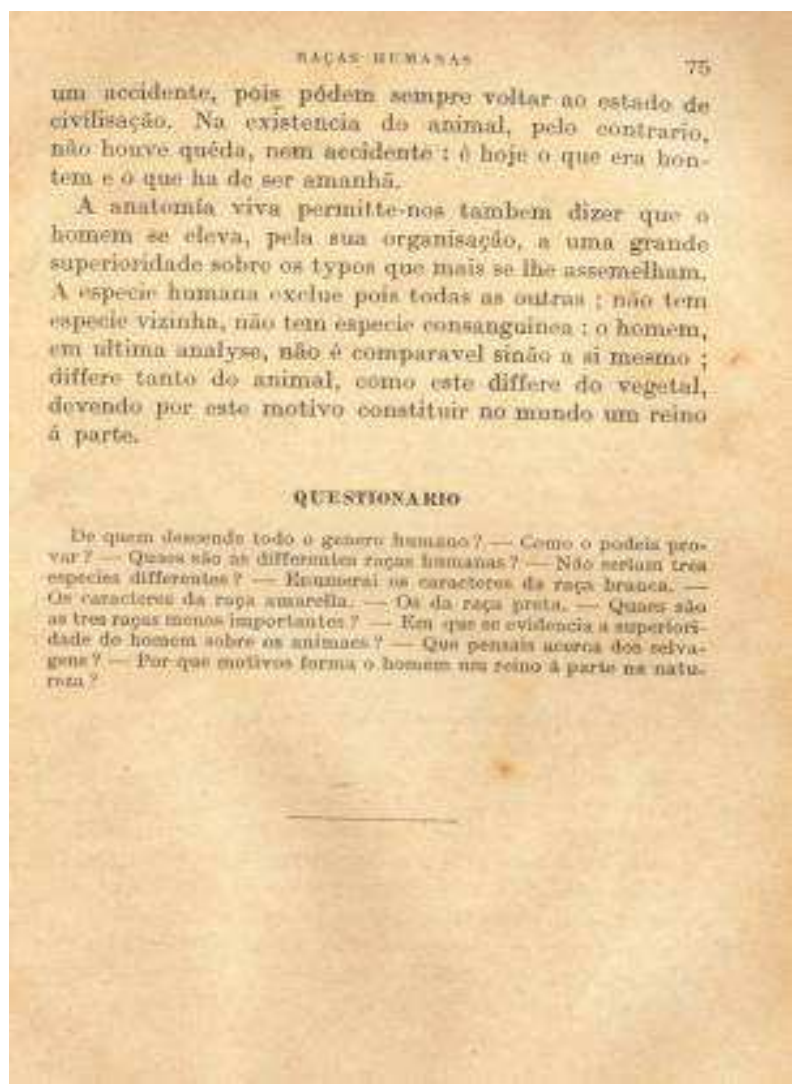

Figura 7: Questionário sobre a origem das especies 


\section{A origem dos seres é descrita como}

A materia cosmica, destinada à compoisção dos planetas, do sol e das estrellas, formava a principio um chaos, ou abysmo escuro e confuso, sem energia actual; começava porém a receber a energia virtual do effluvio divino, que ia organisal-a fecundal-a e vivifical-a.

A vida sobre o nosso planeta nem sempre existiu; e é possival reconhecer, revolvendo as entranhas da terra, o ponto preciso em que, sob o impulso omnipotente da vontade de Deus, ella ahi começou.

Pode-se pensar que, no primeiro instante da creação, só alguns seres foram produzidos com os seus caractereses específicos; por exemplo, os elementos materiaes, os corpos celestes e as substancias espirituaes.

$\mathrm{O}$ apparecimento dos vegetaes precedeu o dos animaes. Entre estes, vieram os animais marinhos antes dos terrestres.

Em seguida aos peixes e os saurios, appareceram as aves; depois, vieram os quadrupedes; e enfim, foi plasmada com mais solemnidade a obra prima de Deus, o Homem, por Elle estabelicido rei da creação.(p. 4-5)

As explicações a respeito do que é o corpo do homem, definem a sua origem

Excellencia do homem. - O Creador não quiz fazer para o corpo do homem um modelo absolutamente differente do animal; mas, ao mesmo tempo que lhe deixou esta fórma material, de-lhe um sopro divino, uma alma dotada de affecto raciocinado, de moralidade ou discernimento do bem e do mal, e de religiosidade.

Há uma distancia enorme entre o poder mental do homem mais infímo e o do simio mais elevado, porque o homem é o unico ser dotado de intelligencia racional no globo terrestre (p.7)

Outro ponto abordado em relação ao corpo humano e que merece atenção é uma das explicações sobre o que é o cérebro

O cerebro é o centro onde vêm ter todas as sensações para serem percebidas pela alma, e donde partem as excitações que determinam os movimentos volutários; é sobretudo a sêde da intelligencia, o orgam manifestador do pensamento.- Todavia, não se deve acreditar com os materialistas, que o cérebro produza o pensamento, de algum modo como as glandulas segregam os diversos liquidos do organismo... Essencialmente simples e immaterial, o pensamento não pode ter por causa um orgam complexo e material: é a alma que pensa; o cérebro não é sinão o instrumento revelador das suas operações. (p. 54)

Podemos observar também no que diz respeito a descrição da raça humana, a definição que o texto apresenta sobre "os selvagens": "selvagens são homens decahidos; mas sua quéda é um accidente, pois pódem sempre voltar ao estado de civilisação. Na existencia do animal, pelo contrario, não houve quéda, nem accidente: é hoje o que era ontem e o que ha de ser amanhã." (p. 74-75).

Outro ponto descreve o aparecimento do homem na terra

Segundo os documentos mais certos, o homem já vivia na Europa durante o segundo periodo interglaciario. Entretanto, a época da sua creação deve 
ser muito mais remota; pois conforme todas as tradições, foi na Asia que Deus creou o primeiro Homem, e, na apparencia, decorreram varios seculos antes que as necessidades da vida obrigassem a familia humana a dispersar-se. (p. 301)

O homem foi creado no maximo gráu de civilização: o estado selvagem veiu posteriormente, como castigo e consequencia de uma civilização viciada. (p.302).

O livro Elementos de História Natural apresenta um conteúdo didático com um grande significado religioso, não somente no que diz respeito ao Homem, mas também relacionado à Educação. É necessário esclarecer que a construção ideológica religiosa do livro foi fruto de uma historicidade concretizada, principalmente em função da relação Igreja-Estado desde os tempos remotos do Brasil Colônia. Os processos históricos desta relação institucional representaram uma disputa pela hegemonia axiológica na sociedade brasileira, sendo o campo educacional uma importante esfera na reprodução dessa debate.

Vale lembrar que, no período colonial brasileiro, a educação religiosa e a dominação política mesclaram-se no interior da sociedade. Neste sentido, "evangelizar" atrelou-se como sinônimo de "aportuguesar". Ao lado do "projeto colonizador" realizou-se o "projeto divino", mediante os quais todos os senhores lusitanos a serviço da Coroa tornaram-se "representantes de Deus", não havendo sentido para a separação entre Igreja e Estado (BRUNEAU,1974).

Embora a Colônia do Brasil se tornasse independente em 1822, a relação IgrejaEstado não mudou após este período. A Carta Política do Império declarava a religião Católica Apostólica Romana como oficial. O Vaticano tentou negociar a relação de autonomia com o novo Estado Imperial. Entretanto, os autores da nova Constituição no Brasil queriam assegurar a "singularidade" do Brasil por meio da Igreja. Por isso, a legislação assinalava que o Imperador seria a primeira autoridade eclesiástica do País. Cabia, pois, a ele a escolha do Clero, o que consolidava assim o regime do Padroado. Pedro II continuou a nomear bispos e outros membros importantes, interpretando como bem queria a extensão de sua jurisdição. Também mediante o Padroado ele recolhia os dízimos da Igreja e pagava o Clero que era tratado como se fossem funcionários públicos. A falta de regulamentação da Santa Sé garantiu ao Imperador a decidisão sobre os negócios da Igreja.

O fato de D. Pedro II administrar a Igreja como um departamento do governo, configurava que nos âmbitos internos do presbitério alguma coisa estava fora do lugar. $\mathrm{O}$ fim do Império favoreceu a unificação da Igreja, de modo que ela não se dividiu na hora da mudança de regime: a maior parte do seu presbitério manifestou-se em favor da República e pela extinção do Padroado.

A Constituição de Fevereiro de 1891 foi mais longe e promulgou leis que refletiram um deliberado afastamento do Estado para com a Igreja Católica. O governo provisório garantia a liberdade de culto a todas as religiões. O clero católico devia ser sustentado pelo Estado por mais um ano, depois deste tempo as autoridades nacionais e estaduais estavam proibidas de subvencionar qualquer religião. Era o fim do Padroado.

Logo após a proclamação da República a Educação foi laicizada, ficando o governo proibido de sustentar as escolas vinculadas à Igreja Católica. A partir de então, a Santa Sé passa a adotar políticas mais firmes junto à Igreja no Brasil, além do mais, não havia um número sólido de sacerdotes em seu presbitério. Assim, a Santa Sé decide apoiar a importação de Ordens Religiosas, especificamente, para a criação de Seminários, Escolas, Universidades. É sob este contexto que chega ao Brasil a Ordem Marista ${ }^{\mathrm{b}}$. 
A expansão educacional das Ordens Católicas no Brasil fixou-se em face de uma política implementada pela Santa Sé, atrelada à contenção de uma crise na Igreja, veiculada ao seu desmembramento com o Estado. Alguns autores (Montes, 1998; Ribeiro, 1993) identificaram esse período como Romanização.

A chegada dessas Ordens Católicas no Brasil deve ser compreendida levando em consideração o contexto histórico internacional, sobretudo no Continente Europeu. O final do século XIX e início do século XX presenciaram momentos de muita efervescência de ideias baseadas no liberalismo e no positivismo. O desenvolvimento de técnicas industriais, a eletricidade, o petróleo, a expansão do capital financeiro são avanços das forças produtivas do mundo moderno, sustentadas do ponto de vista ideológico por essas doutrinas (positivismo e liberalismo) que ratificam o individualismo, a otimização do progresso em função do desenvolvimento de novas tecnologias. Todo esse ideário é transplatado para os planos de ação das Ordens religiosas. Também, nessa ocasião, sedimentava-se o sistema republicano no Brasil, as elites políticas vão abraçar igualmente o conjunto de ideias republicans e a ação educativa das Ordens.

Nesse período, a Igreja vivia um grande paradoxo. Por um lado, certos segmentos do clero achavam que desligando-se do Estado a Igreja teria mais liberdades em sua ação evangelizadora, pois, passaria a não mais ser um simples "departamento do governo". Por outro, alguns membros do seu presbitério acreditavam ser importante o apoio do Estado, em virtude de reafirmar a oficialização do credo católico, ou seja, a manutenção da hegemonia da Igreja Católica. Mesmo reconhecendo os prejuízos obtidos junto às elites políticas, a Igreja buscou uma reaproximação, sobretudo com o intuito de expandir seu presbitério e seu campo de atuação, como também para recompor sua situação econômica.

Da mesma forma, pelo lado do Estado, esse período foi marcado por muitos desafios, em razão de uma série de mudanças e de mobilizações por parte da sociedade civil, a exemplo das revoltas de Canudos, de Contestado, o Movimento de Padre Cícero,etc. As insatisfações da sociedade diante da miséria no campo, pela presença dos sobrecomandos do coronelismo, aliado ao desemprego nas cidades são fatos que desencadearam um clima de descontentamento no seio da sociedade. Ao lado disso, começaram a despontar novos segmentos oligárquicos ligados à indústria, sem contar com o grande contingente de imigração, decorrente do fim da Escravidão. Nesse momento, o Estado e as classes dominantes confiavam no apoio da Igreja, sem contar com o fato de que a população eleitoral, em sua maioria, fazia parte do credo católico.

De volta ao livro Elementos de História Natural, o exemplo da citação que segue reproduz muito bem os ideários propagados no ensino da Ordem Marista, corroborando assim, a otimização do liberalismo e do positivismo:

Todo o homem é filho, de Adão; e, tal como existe e povôa actualmente o globo, a humanidade descende de um par unico. - Igualmente depois do diluvio, a humanidade sahiu de Noé e seus tres filhos; estes déram origem aos tres grupos ethnicos Semiticos, Chamiticos, Japheticos, que se dispersáram por toda a terra. Tão brilhante é este grande facto da unidade de origem dos homens, que é impossível desconhecel-o (p. 72).

Por isso mesmo, pode-se considerar que tanto pelo lado da Igreja, como pelo lado do Estado o apoio mútuo ficou como uma via de mão dupla: os interesses ideológicos foram compartilhados entre os mesmos. Era a seguridade na disputa axiológica entre as duas instituições. 
Portanto, o Homine Cathólico aqui definido é fruto dos ideários históricos das Ordens Religiosas Católicas, cuja representatividade está aqui concretizada na Ordem Marista, por meio do livro Elementos de História Natural.

Ao analisarmos o conceito de Homem em conexão com a Educação, observamos que historicamente as práticas educativas sempre estiveram fundamentadas em alguma concepção de homem, preocupadas em formar um determinado tipo de homem, adequando-o as diferentes exigências conforme à época. A religião católica no Brasil desempenha um papel importante na idealização de um perfil de homem.

No período colonial, a educação foi essencialmente baseada nos fundamentos da Igreja Católica e era ministrada para todas as classes. As práticas pedagógicas eram materializadas por meio da catequese, das normas religiosas impostas e obrigatórias, os castigos, as representações imagéticas, os rituais, os cultos e as pregações. A justificativa de tal formação era um dos modos de sustentação do império Português e católico. A preocupação central era forjar um tipo de homem de acordo com a moral e a doutrina católica, educando-o para a vida daquele tempo (CASIMIRO, 2002). Desse modo, educavam, ao mesmo tempo, "os senhores e os escravos, os possuidores e os despossuídos, os poderosos e os subjugados (...) para o êxito da empresa colonial, para a manutenção do status quo de um pequeno grupo e para a instauração de formas de mentalidades peculiares, que ultrapassaram as barreiras daquele período e que perduram, até hoje, como traços característicos da sociedade brasileira." (idem, p. 114). Os disseminadores da política educacional desse período foram os jesuítas, responsáveis pela organização e regulação da dinâmica educacional da colônia.

O domínio do catolicismo no Brasil permaneceu até a segunda metade do século XVIII, momento em que entrou em crise a partir da implementação da política Pombalina e em consequência a expulsão dos jesuítas.

As reformas pombalinas para a instrução pública, que tiveram reflexos no Brasil, de 1759 a 1834, tinham como eixo central a estatização e secularização dos assuntos relativos à educação, a exemplo da administração do ensino, do conteúdo, da estrutura organizacional dos estudos mediante criação de aulas régias, dos estudos superiores,etc. Isso nos mostra que as reformas implementadas pelo Marques de Pombal chegaram para suplantar o predomínio das idéias católicas, implementando uma nova ordem apoiada nas idéias liberais e concedendo ao Estado o direito de opinar a respeito da matéria instrução. (SAVIANI, 2007, p.113-114).

No entanto, segundo Saviani (2007, p.114), essas reformas não se efetivaram conforme planejadas, uma vez que a grande maioria dos professores tinha formação jesuítica e a colônia não dispunha de meios para arrecadar recursos para viabilizar novas ações pedagógicas. As orientações políticas ocorridas em Portugal (1777 até 1792) depois da morte de Dom José I e o temor da nobreza portuguesa em relação aos avanços da burguesia, que alimentavam desejos de emancipação e disseminavam concepções liberais, também contribuiram para o arrefecimento das reformas. Mais tarde, já em 1792, Dom João VI recupera as idéias pombalinas para a instrução pública, permanecendo os estudos religiosos nos seminários e escolas ligadas às ordens.

Com o fim do regime monárquico e instalação do regime republicano, predominará o pensamento pedagógico laico, liberal e positivista. A Igreja separada do Estado com o fim do regime do padroado precisa restaurar a hegemonia espiritual ameaçada. Um dos passos será cooptar a intelectualidade católica no sentido de chamá-los para servir à igreja e assim restaurar o aparelho eclesiástico. A orientação era instaurar uma Neocristandade para reencaminhar a sociedade aos valores morais do cristianismo católico, uma vez que estavam sendo desvirtuados pelas idéias positivistas. A educação será utilizada como um 
meio de mobilização das massas, buscando romanizá-las. (MESQUIDA, 2008). A concepção de educação presente nas escolas públicas continua sendo de acordo com a visão católica.

A filosofia pedagógica católica sustenta uma definição de homem e de mundo conforme a ética religiosa. Postula que a educação deve se preocupar com o corpo e a alma do homem (pois é a alma que pensa) no sentido de não separar a educação física da educação moral, ensinando o que é o homem, como surgiu a vida e o que acontece após a morte. Apresenta o criador como ordenador de tudo e de todos. (CURY,1986).

A consolidação do sistema republicano foi marcado por ideais liberais burgueses, cujo modelo pedagógico era caracterizado pela necessidade de ampliação das oportunidades educacionais no sentido de transformar os indivíduos ignorantes em cidadãos esclarecidos. Imperava a crença, segundo alguns intelectuais, de que pela educação os problemas do país poderiam ser resolvidos e neste sentido, idealizou-se um projeto político pautado em reformas com o objetivo de moldar o povo "conforme os anseios de Ordem e Progresso de um grupo que se auto-investia como elite com autoridade para promovê-los." (CARVALHO, 1989, p. 9).

Durante o regime de padroado laicizido, as práticas políticas e sociais das classe dominantes adotavam uma concepção de vida sem se preocuparem se as suas idéias entravam em conflito com a Igreja Romana, entetanto, para a população em geral, era disseminada as idéias pedagógicas católicas conforme aprendido nas escolas. O impulso das ideias laicas, influenciadas pelas correntes do liberalismo e do positivismo, sustentada pelas elites, entrou em choque com a doutrina católica, abrindo caminho para separação entre Igreja e Estado e consequentemente, excluindo o ensino religioso das escolas públicas. Uma das formas da igreja resistir, protestar contra essa proibição, restabelecer o ensino religioso e difundir o seu ideário pedagógico foi com a publicação "de livros e artigos em revistas e jornais e, em especial, na forma de livros didáticos para o uso nas próprias escolas públicas." (SAVIANI, 2007, p.179). Os livros reproduziam os ideários das classes dominantes, do Estado e da Igreja em um sistema de ensino acrítico.

O livro Elementos de História Natural tem como fonte de construção do seu conteúdo, um dos instrumentos historiográficos mais poderosos já construídos pela humanidade que é a Bíblia, com argumentação fortemente ideológica implementou um sistema educacional interinamente voltado aos ideários das classes dominantes: tudo conforme a vontade de Deus, contribuindo para a formação de um homem apático, acrítico ao reproduzir uma prática educacional religiosa endógena, privada, não militante e passiva, que não colabora para a formação de sujeitos ativos politicamente.

\section{REFERÊNCIAS}

BRUNEAU, Thomas C. Catolicismo Brasileiro em Época de Transição. São Paulo: Edições Loyola, 1974.

CASIMIRO, Ana. P. B. S. Economia cristã dos senhores no governo dos escravos: uma proposta pedagógica jesuítica no Brasil colonial. Salvador, 2002.p. 480.2v. Tese

(Doutorado em Educação). FACED - UFBA.

CARVALHO, M. M.C. de. A Escola e a República. São Paulo: brasiliense, 1989.

CURY, Carlos R. J. Ideologia e educação brasileira: católicos e liberais. São Paulo: Cortez, autores Associados, 1986. 
MESQUIDA, Peri. O processo político de restauração da igreja: educação e os intelectuais orgânicos (1916- 1940). Revista HISTEDBR On-line, Campinas, n.31, p.31-40, set.2008. Disponivel em: www.histedbr.fae.unicamp.br.

MISSÃO EDUCATIVA MARISTA : um projeto para nosso tempo / Comissão Interprovincial de Educação Marista (1995-1998). Tradução Manoel Alves, Ricardo Tescarolo2. ed. São Paulo : SIMAR, 2000. Disponível em:

http://www.champagnat.org/pt/220505000.asp

MONTES, Maria Lucia. As Figuras do Sagrado: entre o Público e o Privado. In: NOVAIS, Fernando A. (org.). História da Vida Privada no Brasil. São Paulo: Comp. Das Letras, v. 4, 1998.

RIBEIRO, Ivete \& RIBEIRO, Ana Clara Torres. Família e Desafios na Sociedade Brasileira: Valores como um ângulo de análise. São Paulo : Edições Loyola, 1993.

SAVIANI, D. História das Idéias pedagógicas no Brasil. Campinas,SP:Autores Associados, 2007.

SITES

www.ftd.com.br

www.maristas.org.br

${ }^{a}$ Homine Cathólico significa Homem Católico em Latim.

b Alguns exemplos de outras Ordens que chegam ao Brasil no mesmo período vão reforçar esta afirmação: Salesianos em 1883; Sagrado Coração de Jesus em 1900; Santíssimo Sacramento em 1903. 